\title{
THE DUAL MANDATE FOR TOMORROW ${ }^{\mathrm{I}}$
}

\section{EMORY ROSS}

TORD LUGARD, in a good deal of his action as well as in his speaking and 1 writing around the turn of our present century and later, gave prominence and helped to give progressive formulation to an idea which had not then been nearly so clearly seen, accepted, or practised as it has been in certain quarters since.

This idea may be paraphrased by saying that a balance should be maintained in colonial relationships between the good resulting for the colonial peoples and that accruing to the governing peoples.

A re-reading today of Lord Lugard's The Dual Mandate in British Tropical Africa and some others of his writings is instructive in a number of ways, not the least being that it gives us among other things this 'balance' measuring-stick with which in some degree to measure our position today. How is that balance which Lord Lugard urged between colonial and governing peoples to be gauged today?

Perhaps, for one thing, it can be said that more people today would agree that this balance is one which has everything good to commend it. Many might also agree that where such balance has been best maintained, there one can find some of the best relationships in the world's colonial experience. But some of the same people and many others might hold likewise that the failures to maintain such a desirable balance have been so numerous, so long-standing, and so serious as to contribute very considerably to the difficulties men face today in colonial relationships.

If this be so, one may reasonably ask why failures in this field have been of such magnitude as to put us all in the situation we are in today? Why is it that the very practical and often-praised dual mandate so cogently supported by our honoured colleague of the years, for so long the influential Chairman of our Institute, has not been more consistently carried out and in consequence more effective than it has been in preventing the rise of colonial tensions, fears, and bitter struggles?

Let me suggest four developments in our world society which have contributed to these failures.

First, it has happened in the past fifty years that Western Europe and the Americas have made such scientific and material progress as has been almost undreamed of in all the centuries of man's life on earth. It was quite impossible for Lord Lugard, or for any of us living fifty years ago, to foresee with any clarity and certainty what this half-century would produce, either constructively or destructively.

Building on the past, these developments have, in material things, enabled much of the Western world to make greater progress in wider fields than ever before in history. Thus the West, in material progress in this half-century, has far outstripped colonial areas both absolutely and, in all probability, relatively. A 'balance', therefore, such as Lord Lugard perhaps envisaged has not been possible either in relative or absolute terms.

It must not be thought that this Western advance has been wholly at the expense

I The text of the Lugard Memorial Lecture, delivered in Lisbon on 6 July 1953 , on the occasion of the meeting of the Executive Council of the International African Institute. 
of the colonies. For the greatly increased advance of the West has certainly not been principally because colonies existed and could be 'milked', although colonial contributions to that advance, particularly of raw materials and human labour, have been important.

The fact stands out that 'balance', in this colonial era, has proved impossible as between colonial peoples and governing peoples partly because of the unforeseen and unprecedented material advancement of the West.

Second, the advancement in material ways of something like 160 million colonial peoples in Africa south of the Sahara has not been possible, either through their own efforts or through the efforts of others aiding them, at the rate at which perhaps some in the West fifty years ago thought it could occur. Even had there been all the goodwill in the world on the part of all the governing peoples, which there was not, it is still unlikely that the colonial peoples could have managed material advances in fifty years at a rate which, measured relatively, would have equalled even a normal fiftyyear advance of the West.

This is not to detract in the slightest from recognition of the extraordinarily rapid strides made by hundreds of thousands of Africans in this past century, or of the great individual and collective accomplishments of tens of thousands of African leaders in the past quarter-century. It seems probable that, both in degree and speed, no such mass change has previously occurred in our world. But the West, from an advanced base, in many ways went faster.

The West, even for a normal progress, had a running start in education, science, invention, technology, credit, manufacture, distribution, which probably African colonial peoples, just emerging from primitive animistic communalism, could not have made up in so short a period. There were neither the economic resources plus competent and devoted personnel outside Africa, nor the human and physical resources within Africa to make possible even under optimum conditions such a 'balance' as I have here paraphrased from Lord Lugard: a type of balance which seems to me the only kind, if material measurements alone were to be used, which might have avoided to any considerable extent the tensions and other difficulties of the colonial situation today.

If there were reasonable doubt about Africa being able to keep some sort of balance even with ' normal 'Western advance, there can be none whatever when one views the abnormal, indeed unprecedented, material advance made by the West in the past fifty years. Africa, for the most part, was left farther and farther behind in that period, both relatively and absolutely.

But even so, the crises of today in colonial matters might not have reached their present stage if a third element had not intervened. This third element is itself a part of the unprecedented advance of the West in the past half-century but it is of such a special and penetrating character that it requires consideration in its own right in a situation such as we here examine.

This third element is communications-communications in the broadest sense, in the most inclusive meaning of the term. It begins truly with education, with the passing on of knowledge, with the interpreting of life from one generation to another, and from specialist to learner, from expert to apprentice. It includes literacy, books, magazines, newspapers, personal correspondence. It embraces post, telegraph, cable, 
telephone. It expands by wireless, by radio, by television. It takes in films : dramatic, documentary, educational, newsreel, propaganda films - the good, the medium, and the bad in each category. It develops what are known as public relations-a form of communication highly personal and one of the most expensive businesses in the world. It moves from transportation by foot, paddle, and animal, on to railways and then on to automobiles, airplanes, and to jet and supersonic movement. It utilizes electronics to multiply unbelievably all current forms of electric communications. It moves persons from place to place by billions of man-miles per year. It creates global exchanges of tens of thousands of persons every year for education, research, commerce, assemblies and conventions, work-camps, sight-seeing, sports, dalliance, sunburn, and for meetings of the International African Institute. In sum, it lets every people get to know something about every other people-not always the truth, but something, and quickly.

- Never have people known so much, so quickly, so widely about so manyespecially, perhaps, about the bad things in life, particularly the bad things in the lives of others : the weaknesses and excesses of others; the things they have which we lack; their greed which tends to our impoverishment; their prejudices which make for our exclusion; their power which sucks at our weakness."

It is impossible to say what the world would have been like today had this enormous complex of communications not been intertwined in the astonishing development of the past fifty years. It is a part of the warp and woof of the fabric of our time, inextricable, inseparable.

- But I venture to say this about it in relation to colonial Africa: that without this immense, incessant, and all-pervading power of communications the colonial crisis would not be as sharp, as wide, or as difficult as it is today. For Africans and Westerners and Easterners would, none of them, have known so much about each other and about African situations as they do. We would not be daily informed about Mau Mau or about apartheid. Strikes in the copper belts over low pay or colour bar would be known to but few Africans and fewer outsiders. The problems of Indo-China, of Timor, of Goa, Malaya, and other colonies would not be widely available to the public without this giant of communications. Neither would the 200 per cent. dividend of De Beers last year, nor the great profits of other diamond companies, nor those from copper, uranium, rubber, iron, and other African products. The ineptness of the United States in certain aspects of its Mutual Security aid for Africa would have been little known. "

"And on the other side, Africans would have been much less aware of the giant strides made technologically and economically by the West in the past fifty years. Not knowing this, they likely would have felt somewhat less than many of them now do that they, the Africans, have been chiefly responsible, as colonial sources of raw materials and of labour to get those materials out of the earth, for this increased wealth and advance of the West."The Western man's economic view of Africa's part in this Western advance differs considerably, I should judge, from the African view and is doubtless better informed although perhaps not less biased. But the point here advanced is that modern communications have put the African in possession of his view of the matter in a way not possible had those multiple communications not existed. 
The racial discrimination found in the United States, and in various forms in other parts of the West, would not have been known to the African as it is if this complex of communications had not developed. Colour sensitivities might not have been so high on both sides of the line of colour as they today are in many parts of Africa and of the world had not this pervasive communications system existed.

But it is the fourth of these four factors to which I refer which seems to me to have even greater basic influence on the colonial misunderstandings in our world today than any other, and on many misunderstandings and conflicts in other parts of the world, too, beginning in the very heart of the West. This fourth factor is an omnipresent and pervasive one also, as is communications, but it is even more important since it ultimately determines the content of what is to be communicated.

This fourth factor is the split which has developed in the West-accentuated in the past fifty years but with its beginnings back beyond that-between the spiritual and what we call, with a rather special meaning, the secular-' secular' used with the intimation that it is an area rather outside and perhaps beyond the reach of what we call the 'spiritual'.

This intellectual tendency of the West to separate life into sectors and to call one ' secular' - or by any other name-as the sector in which realism and objectivity and ' hard facts' alone can operate acceptably and effectively, has spread rather widely in modern times in the West. It has reached the point where in perhaps most of the countries of the West education, particularly higher education, is set in this secular framework as defined above, separated as completely as possible from religion. This is done in the face of what seem to many to be two important facts:

(I) That education, including higher education, in almost every corner of the West has been pioneered by religious bodies and personalities, and has in the end been the bulwark of freedom which has permitted public education and all its branches to grow and to fruit; and

(2) That realism and objectivity and 'hard facts' all show that man is body, mind, and soul, all three, and that in most of the great personal and collective crises of life it is ultimately the soul that rules, whether for high or low, for victory or defeat, for life or death. It would seem that no factor so important and so demonstrable in life as this is should be ruled out of education on the ground of realism and objectivity. Indeed, there would seem to be unrealistic and biased judgement at the root of such a ruling.

We in the West all know the historic and experiential reasons for this decision, as it was progressively taken in our lands, to try to bar off the spiritual from the secular. In the mistaken deterministic and authoritarian attitudes of at least some religious personalities of all confessions in generations past there appeared the tendency to stifle the hunt and search for truth, for knowledge, for the new and the untried, for daring into the presently unknown to see what could be learned for use tomorrow.

But it seems clear, too, that on the whole the Christian religion, despite the human imperfections of its followers, has been, in the souls of men, the greatest factor in the life of the West in making possible this unprecedented advance of the past fifty years which we today consider. For what other force has done more than the Christian religion at its best to free men's minds to think, to try, to venture, to experiment, to invent, to dare, and in the end to accomplish? Where that religion has been at its 
best there the bounties and wonders of nature have been best discerned and put to man's use. Where the Christian religion has been at its best, despite human frailties, there it seems to me is to be found the greatest stability combined with mobility, the greatest confidence and faith and power in our distraught world today. Where the Christian religion is at its best, there the inroads and fears of the Godless 'isms' of our age seem least, and the overt threat of those 'isms' is at its smallest.

But while the Christian religion at its best has helped to give this freedom to man, its measurable failure among men has been in not assuring the indispensable accompaniment of that freedom-man's sense of responsibility for the use and results of that freedom. Thus it is that one of the greatest freedoms of all time-the freeing of the atom's power for untold new and direct human services-has become one of the greatest dangers of all time. Man himself is not assured and determined in his responsibility to control the results his freedom gives.

So it is in the world's colonial relations, also. The West's great advance in the past fifty years could have been more of a promise and less of a provocation for colonial peoples if two things had accompanied that advance:

(I) A feeling and a demonstration, continuingly clear, that the West was prepared to share progressively and generously its gains of various kinds with the world's colonial peoples at a pace geared to the striving of the colonial peoples to receive and utilize them well; and

(2) A development of true confidence in the minds of the colonial peoples that the governing peoples were sincere and honest in those intentions.

Ah, yes, men say, if you could do these things the position would be bettered; if a willingness to share and a confidence in that willingness could be established, the world would be a different place. But how, how can that be done with men and nations as they are? How?

The basic answer to this ancient query lies squarely in the realm of the spirit. It is only by the useful exercise of the spiritual power which every man commands-if he wishes to-that the basic answer to this ' How' can be given.

Yet concerning these material, these 'secular' matters it is precisely in the realm of spiritual control that we are weakest. We Westerners are weak because we have too long and too much separated our spiritual from our secular. We are at a loss to know how to put them acceptably and effectively back together again.

Africans are weak because their spiritual controls, those of their animistic religions which for generations have controlled almost every detail of their lives, are almost completely inadequate for, and are indeed a great handicap in, the new, different challenging life which is flowing in upon them.

They are also no doubt, many of them, confused, even baffled, by the knowledge now dawning that the extremely promising Western religion, Christianity, seems to contain this clear split between the spiritual and much that we in the West distinguish as 'secular'. This is a distinction and a separation which is not generally found in their animistic communal society, any more than it was found in the early JudaeoChristian community. They cannot believe that the 'secular' is totally bad and that the 'spiritual' is not to be sullied with it. The 'secular', as they seem to see the West defining it, contains necessities and much of the high good of life itself. It is inextricably a part of life. Neither can they believe that the 'spiritual' is so sacred, so 
biased, or so weak that it is not to be related to this whole life. To them it is an indispensable, indeed, a controlling part of life.

Is there not here a lesson for the West to re-learn? That man is one within himself? That in man the 'secular' has great good and has also its human content of bad? 'That, man being man, the 'spiritual' in man is never perfect and pure? That the real struggle in man is between the good and the bad, not between something called 'spiritual' and something called 'secular'? That in this struggle there should be linked tightly together all the good in both the 'spiritual' and the 'secular' against all the human bad in both?

In the world's colonial relations both the Westerners and the Africans need a new balance between the spiritual and the secular.

It is just this which I suggest now as the dual mandate for tomorrow : that Westerners and Africans separately and together seek to establish and maintain, with all the understanding and flexibility which a growing human society requires, a new balance between the spiritual and the secular in their lives and in their doings. For such a new dual mandate has this inestimable advantage over any other: that its basic striving is for balance within the lives of both Westerner and African, rather than for a balance between the lives of Westerner and African. When balance and serenity rule within, the relations without are never so hard.

Now let me suggest briefly and in closing how such a new and realistic balance between the spiritual and the secular within the lives of African and Westerner could illumine change, kindle hope, bridge differences, build understanding and hence confidence, and speed progress.

The West has imposed its laws upon African society. Some nine different national codes of laws, if my count is right, have been imported with greater or smaller modifications into African life in the past century. These codes have considerable variations among themselves, but they all have this base in common: they were formed in societies whose education and ethics were in general Christian. Merely by reason of this fact these codes of laws were, all of them, in important particulars incomprehensible in, and incompatible with, an African society based on animism.

Take only one example in this realm of law : a Western requirement of an eye witness to a murder conflicts directly with an African belief in spirit-possession, a religious belief which leads logically to a conception of murder by an enemy through spirits which no human eye can ever see.

Much in our Western secular law is out of balance spiritually with African society. A new religious conception replacing animism and illumining Western law is an example of the new balance required between the spiritual and the secular in Western and African relationships.

Or, among the new economic concepts imported into Africa, let us take credit and retail trade as an example. In an African communal society the controlling spiritual beliefs about goods, possession, barter, blood-group responsibilities, dowry, continuing gifts to the wife's family, and the like are serious obstacles to retail trade, inventorying, monthly statements, credit, debts, and other elements of a cash economy on the individualistic Western pattern. For the African a balance is lacking between the old spiritual and the new secular. Until that balance begins to appear the misunderstandings between Westerners and Africans about honesty, truth, probity, 
integrity, reliability are likely to continue to poison relationship far beyond the site of the retail store.

In medicine and public health, Western pattern, it seems doubtful that any African can become an adept and really useful practitioner until his religious beliefs about the causative and curative aspects of disease are at least in process of change to something approximating to the Western religious bases underlying Western medical science and practices. A balance here between the spiritual and the secular is required.

I mention only one more instance, so obvious that it is often-indeed usually, it would seem-overlooked in Western-African relations. This is agriculture, basic to the whole future development of African society. Is it really intelligent for Westerners to think that the lure of money crops, or the compulsion of tax levies, or the fear of police actions are of themselves likely deeply to change the attitude of hundreds of thousands of Africans regarding land, its cultivation and the very important tribal responsibility of safe-guarding and satisfying the powetful spirits within and controlling Mother Earth? Or that the example and demonstration of improved Western farming by Westerners, possessing as they do, in the African's view, their own special and obviously potent Western 'medicine', is likely to convince the mass of Africans that they, Africans, lacking this Western medicine, can dare to use those Western methods successfully against the well-known tradition and desires of their ancestral and other spirits controlling Mother Earth and all of man's relationships to the earth?

Economic and physical force and the power of example admittedly can do something to get crops currently produced under their compulsion. Some individuals may be inwardly reoriented toward the land by such external forces. But it is not surprising if generally the African reaction to physical compulsion to produce new or larger crops is resentment, resistance, fear-all of them attitudes which can in the end build hatred.

It is to be doubted whether the mass of the African animistic communal society can be brought to an essentially new and productive attitude toward land until their religious beliefs begin to change. A new balance between the spiritual and the secular is required.

Examples could be continued at length of the practical and almost universal need of this new balance between the spiritual and the secular in the whole complex of Africa's changing society today. For almost all of the details of traditional African life are based on, and controlled or influenced by, the African animistic religions, and almost all of the bases of the new life coming in upon them from the West are of Judaeo-Christian origin-vastly different after 4,000 years of growth out of a somewhat similar animistic communalism.

Westerners, for their part, badly need this re-established balance between the spiritual and the secular so that they may, in their own society, better understand and more safely control the science, technology, and power which they have unloosed upon themselves and upon the rest of the world; and so that they may, in their ever closer relations with colonial peoples, present the spiritual bases and interpret the spiritual philosophy upon which the important and good elements of their Western life are based.

Africans also badly need this new balance established, for without it the old 
religious bases and controls disappear and no new ones come. The result? The African becomes uncertain, confused, insecure, unrooted, baffled, resentful, fearful. He begins to strike out at all around him because he doesn't understand, he feels no certain strength, no security, no peace.

The re-establishment of this balance between the spiritual and the secular cannot be done by religious missions alone. For man is one, a whole. Society has many parts, but to be strong and to grow they all must work together. A great African of our generation phrased this thought on the piano keyboard. Said Aggrey, "To produce true music, both the black keys and the white must be used.'

A second great African of our generation phrased his thought in a remarkable treatise on 'holism'. General Smuts saw clearly and described persuasively the wholeness, the oneness of life, and the power of the spirit in that life.

The call is to all men of Christian heritage to plan and work, personally and collectively, for the re-establishment and maintenance of the indispensable balance between the spiritual and the secular. Only so is this world to be free and to be kept free-by men of good-will everywhere sharing freedom and sharing the free responsibility therein wisely to control the incalculable results of such freedom. Good never overcomes evil merely because it is good.

Cobden once said, all things shall yield to energy. The world today knows two sources of inexhaustible energy : the atom, and the soul. The world today is fearfully aware of the atom. The world today seems doubtfully aware of the soul.

Yet in the end it is almost always the soul that can rule.

A re-won balance between the spiritual and the secular is man's dual mandate for tomorrow.

\section{Rêsumê}

\section{LE DOUBLE MANDAT POUR L'AVENIR ${ }^{I}$}

LORD LugARD, par ses ouvrages et ses activités, avait énoncé le principe que dans les rapports coloniaux un équilibre devrait être maintenu entre le bien qui résulte pour les peuples coloniaux et les avantages afférents aux puissances colonisatrices. Actuellement, il faut bien se rendre compte que cet équilibre n'a pas toujours été maintenu, et que ce défaut de le réaliser a occasionné les rélations tendues et les crises dans les affaires coloniales auxquelles nous avons à faire face. Quatre facteurs ont contribué à cet échec: $x$. Le progrès remarquable, tant matériel que scientifique, réalisé dans l'Europe Occidentale et dans les deux Amériques au cours des so dernières années. 2. L'impossibilité pour les peuples coloniaux de progresser avec la même rapidité. 3. Les développements extraordinaires dans les moyens de communication de toutes sortes-l'instruction, la presse, la radio et les transports-qui ont eu comme résultat la propagation sur une vaste échelle de connaissances diverses parmi les peuples, de sorte que chacun sait davantage sur autrui, mais pas toujours avec des effets souhaitables. 4. La dichotomie crée dans l'Occident entre les domaines spirituels et temporels. Cette dichotomie néglige les faits qui sont d'une importance primordiale, soit qu'un homme possède un corps, un esprit et une âme, et que l'instruction dans l'Occident a été instituée par des organisations religieuses. La religion chrétienne a été le facteur fondamental dans le progrès intellectuel de l'Occident; elle a incité les occidentaux à

Texte de la Conférence du Prix Lugard, faite à Lisbonne le 6 juillet 1953, à l'occasion de la réunion du Conseil Exécutif de l'Institut International Africain. 
obtenir leur liberté et leur certitude, leur hardiesse et leur pouvoir. Cependant, elle n'a pas réussi à leur donner un sens de responsabilité dans l'emploi de leur liberté et de leur pouvoir. Les occidentaux n'ont pas su démontrer clairement, et d'une façon soutenue, leur empressement à partager leurs gains intellectuels et matériaux avec les peuples coloniaux, ni à les convaincre de la sincerité de leurs intentions de réaliser cette participation. La source de cet échec réside dans le domaine spirituel. Les occidentaux manquent de force en ce qui concerne la maitrîse spirituelle par suite de la séparation entre le spirituel et le temporel; et les Africains, en raison du fait que leurs religions anciennes sont insuffisantes, et même présentent des inconvénients dans la situation qui existe actuellement, sont également impuissants. Les Occidentaux et les Africains ont besoin les uns et les autres d'un équilibre nouveau entre le temporel et le spirituel dans leur for intérieur, et si cela pouvait être réalisé, les rapports entre eux deviendraient moins tendus.

Les systèmes des lois, les idées concernant la médecine et la santé publique, même le développement de l'agriculture et du commerce, que les sociétés occidentales ont imposés aux Africains, sont tous basés sur des idées fondamentales, qui sont complètement étrangères à l'esprit africain. Pour l'Africain, ses idées religieuses traditionnelles pénètrent dans tous les aspects de la vie et les efforts en vue de l'obliger de changer ses conceptions de la loi ou sa façon de pratiquer l'agriculture ne font que soulever en lui le ressentiment, la crainte et même la haine. Ce n'est, par conséquent, que si des maitrîses nouvelles spirituelles remplacent les anciennes et qu'un nouvel équilibre entre le spirituel et le temporel est réalisé que l'Africain trouvera la sécurité et la confiance dans la situation compliquée et changeante à l'heure actuelle. C'est de cette façon seulement que l'homme occidental sera en mesure de comprendre et de contrôler les forces nouvelles qu'il a déchainées sur le monde, et que les rapports entre les peuples coloniaux et l'Occident seront établis sur une base sûre. Cette tâche ne peut pas être accomplie par des missionnaires seuls. Il est indispensable que les hommes de bonne volonté partout dans le monde participent dans la liberté et dans la responsabilité pour la maitrîse des résultats incalculables de la liberté. Nous connaissons deux sources inépuisables d'énergie: l'atome et l'âme, et, en fin de compte, c'est l'âme qui sera capable de gouverner. 